\title{
200TH ANNIVERSARY OF THE BIRTH OF MAX VON PETTENKOFER (1818-1901), THE FOUNDER OF OUR MEDICAL DISCIPLINE - HYGIENE
}

\author{
Vladimír Bencko \\ Institute of Hygiene and Epidemiology, 1st Faculty of Medicine, Charles University and General University Hospital, Prague, Czech Republic
}

The rapid development of industrial society in the 19th century was accompanied, among other things, by rapid population growth in urban centres, and excessive pollution of waterways and air. The rapidly growing urban agglomerations have been overwhelmed by frequent epidemics of typhoid fever and cholera. In 1865, Max von Pettenkofer lectured on hygiene at Ludwig-Maxmilian University of Munich, and in 1879 he founded the Hygiene Institute at the Medical Faculty at Munich University. Since the second half of the 19th century, Max von Pettenkofer has been pushing for $\mathrm{Mu}-$ nich to build a central sanitation slaughter and a system for safe drinking water that the city has undergone - healed and helped to avert the threat of major epidemics of cholera and typhoid fever. Establishing sewerage and central distribution of safe drinking water without the use of lead pipes, similar to the establishment of central city slaughterhouses, has become a good example and a way of combating large-scale epidemics of intestinal infections in urban agglomerations. Epidemiological approach applied by Max von Pettenkofer promote the construction of sewerage systems and the establishment of a central distribution of safe drinking water to the population and it was recognized worldwide.

Max von Pettenkofer together with Robert Koch had a significant influence on the development of hygiene in Europe in the second half of the 19th century, having grew up a number of pupils - important scientific prominent personalities such as Isidor Soyka and Gustav Kabrhel, founders of the Prague School of Hygiene (1-3).

Max von Pettenkofer was born on December 3, 1818, in Lichtenheim, Bavaria. He studied pharmacy, chemistry and medicine. He was inaugurated Professor of Medicinal Chemistry at the Medical Faculty in Munich in 1847 and later appointed the director of the Royal Pharmacy of Bavaria (1850-1896). The life and professional path of this outstanding scientist of the 19th century was influenced by Munich, in which Max von Pettenkofer grew up and received education at pharmaceutical and medical faculties, received approbation as a pharmacist, became a doctor of medicine, surgery and obstetrics (4-6). After further study of chemistry, he was appointed Professor of Medicinal Chemistry at the University of Munich, where he was also appointed the Dean of the Faculty of Medicine at Ludwig-Maximilian University (1867).

The scope of scientific work of Max von Pettenkofer is incredibly broad. Fifty-eight of his 200 published papers deal with cholera, the prominent issue of public health care at the time. To solve the crucial problems, it was the introduction to maintaining public health, detection and metabolism of cholic acid, hippuric acid and detection of the metabolic cycle of creatinine and constructed breathing apparatus. He was a person with great talent and enthusiasm for scientific work, with a focus on current issues and he brought many solutions ahead of time.
After a cholera epidemic in Munich in 1854, he focused on this issue for years to come, approaching solutions particularly from epidemiological view, issuing a series of regulations, opposing faecal seepage pits mainly around wells for drinking water and he consistently championed the construction of the sewerage system and drinking water supply without the use of traditional lead pipes. In doing so he personally participated in the implementation of the projects, which Munich made one of the first cities in Europe more safe. As a result of that he became the first full Professor of Hygiene in Germany. In 1879, he founded the Hygienic Institute at the local Medical Faculty at Ludvig-Maximilian University and led the institution for twenty years. Epidemiological analysis of incident cases of typhoid fever and cholera epidemics led him to the realization that the most common source of infection becomes drinking water, and he created the theory of infection causes so-called "Miasma". In his imagination poisonous vapours of moist soil is also enriched by decomposing organic materials including also fecal waste. He unfortunately mistakenly insisted on the Miasma theory even after Robert Koch in 1883 definitively identified the cause of cholera - Vibrio cholerae.

Max von Pettekonfer's dwelling on this erroneous interpretation of the originator of cholera led him in 1892 to an attempt on his own to demonstrate that the transmission of cholera is influenced by several different factors (8). In description of this experiment is always emphasized that Pettenkofer prior to ingestion of the pure bacterial culture drank certain amount of natrium bicarbonate to neutralize the acidic environment of the bactericidal content in the stomach. Link to the work of his pupil Gustav Kabrhel, which discussed the effects of (acidic) gastric juice on pathogenic microorganisms, executed three years before by Kabrhel in Munich, is more than obvious. To prevent Max von Pettenkofer from cholera and to prevent initiation of a cholera epidemic, Robert Koch prepared an attenuated strain not-toxicogenic Vibrio cholerae (5).

Max von Pettenkofer unforgettable merits include the foundation of the Archive for Hygiene in 1889, in his time the best, internationally respected journal in this branch of medicine.

Max von Pettenkofer had five children, three of them died from infections. When his wife died after 45 years of marriage, he fell into deep depressions and resigned from all scientific and public positions in 1899. In 1901, after a serious infection in the throat area, in depression, deprived from sleep reportedly for two weeks, he decided to commit suicide (9).

Max von Pettenkofer's fame and significance far surpassed his time: this is also evidenced by the respect for his memory, which was demonstrated in 2007 by a team of authors led by $\mathrm{K}$. Trulzsch giving the name of the 50th isolated staphylococcus strain the Staphylococcus pettenkoferi (7). It can also be noted that at the oldest educational institution in public health sector 
in the USA, University of John Hopkins, the Institute of Public Health is named after Max von Pettenkofer (2). The memory of Max von Pettenkofer's legacy can also be commended by quoting his famous verses:

"The art of healing can alleviate many pains, the more beautiful is the art,

which can prevent disease earlier

before it breaks out".

Max von Pettenkofer life journey is a successful combination of scientific efforts, exceptional ability to solve technical problems and ability to concentrate on tackling the prominent community problems, in his case of Munich, where he lived and worked purposefully. After all, his model of expert behaviour in public health is valid in the 21st century as well. His error in dispute with Robert Koch's younger generation is an exemplary example of how difficult it can be to promote new ideas among and inside academic community. In the current promotion of evidence-based medicine is a prerequisite for real progress in respect to the current social situation, including the phenomena of social pathology $(6,9)$. It is e.g. increased incidence of drug addiction, housing maladjusted social groups, homelessness, and activity of anti-vaccinators, to give some concrete examples of chronically known risk factors: obesity, lack of physical activity and increasing stress levels. Our strategic hope in time of marketoriented medicine we see in that the steadily rising cost of treating patients sooner or later will lead to a gradual understanding of the importance of primary prevention, today in Cinderella position, and real implication of principles of "evidence based" into the everyday practice of public health, i.e. hygiene and epidemiology as their biomedical branches.

\section{REFERENCES}

1. Klein O, Bencko V. Max Josef von Pettekofer (1818-1901) - the "high priest" of Hygiene. Hygiena. 2008;53(4):143-5. (In Czech.)

2. Wildner M, Schlipkoeter U. Max von Pettenkofer. Lancet. 2001 Sep 1;358(9283):765.

3. Nazaroff WW. Max von Pettenkoffer award. Indoor Air. 2012 Dec;22(6):443-5.

4. Hlaváčková L, Svobodný P. Biographisches Lexikon der Deutschen Medizinischen Fakultät in Prag 1883-1945. Praha: Karolinum; 1998.

5. Klein O. Gustav Kabrhel and Prague Hygiene School. Čas Lék Čes. 1992;131(6):186-7. (In Czech.)

6. Oppenheimer GM, Susser E. Invited commentary: The context and challenge of von Pettenkofer's contributions to epidemiology. Am J Epidemiol. 2007 Dec 1;166(11):1239-41; discussion 1242-3.

7. Petráš P. The Jubile 50th staphylococcus, Staphylococcus pettenkoferi. Zpr Cent Epid Mikrobiol. 2007;16(7):314-7. (In Czech.)

8. Ruckdeschel G. Max von Pettenkofer. Čas Lék Čes. 1990;129(30):959. (In Czech.)

9. Morabia A. Epidemiologic interactions, complexity, and the lonesome death of Max von Pettenkofer. Am J Epidemiol. 2007 Dec 1;166(11):12338 .

Prof. Vladimir Bencko, MD, PhD Institute of Hygiene and Epidemiology, 1st Faculty of Medicine, Charles University and General University Hospital Studničkova 7, 12800 Prague 2, Czech Republic E-mail:vladimir.bencko@lf1.cuni.cz 